\title{
CASA PARA QUEM NÃO TEM LAR: UMA PERSPECTIVA BÍBLICO-TEOLÓGICA DOS DIREITOS HUMANOS DOS REFUGIADOS
}

House for the Homeless: a Biblical - Theological Perspective on the Human Rights of Refugees

\author{
Adriano Sousa Lima * \\ Kenner Roger Cazotto Terra **
}

RESUMO: Dialogar com os desafios contextuais e tornar a vida lugar privilegiado de releituras da tradição bíblica faz da interpretação das Escrituras uma ação política. De outra forma, o discurso sobre a fé perderia sua relevância e acabaria respondendo a perguntas não feitas. Nesse sentido, é fundamental para a teologia bíblica ser conduzida por perguntas complexas e relacionadas às questões urgentes. Entre tantas, a movimentação migratória, os refugiados e suas implicações política, sociocultural e econômica surgem no cenário mundial como grande desafio entre as nações. Essa discussão, como mostram as recentes pesquisas, desemboca nas preocupações relacionadas às violações de direitos e da dignidade humanas. Dessa forma, para ensaiarmos uma leitura bíblica contextualizada aos desafios migratórios e a crise dos refugiados, à luz dos Direitos Humanos, o trabalho fará a descrição da história do tema em perspectivas jurídicas e sociais. Depois, tendo como contexto de análise o desenvolvimento do conceito, ensaiar-se-ão exercícios hermenêuticos a fim de propor uma teologia bíblica a partir da preocupação com a questão dos refugiados. Para isso, os termos "peregrinos", "estrangeiros" e "justiça" segundo a Bíblia Hebraica e o Novo Testamento serão fundamentais.

PALAVRAS-CHAVE: Refugiados. Direitos Humanos. Estrangeiros. Justiça. Teologia.

\footnotetext{
* Centro Universitário Internacional UNINTER, Faculdade Batista do Paraná, Curitiba, Paraná, Brasil.

** Faculdade Unida de Vitória, Vitória, Espírito Santo, Brasil.
} 
ABSTRACT: The interpretation of the scriptures can become a political activity in the form of dialoguing with contextual challenges and reexamining the biblical tradition in the contextual realities of today. Otherwise, the inquiry on faith may lose its relevance, which can lead to providing answers to non-existing questions. Therefore it is fundamental for biblical theology to address difficult questions that are related to urgent demands. Meanwhile the movement of migration, refugees and their implications on politics, socio-cultural and economics appear to be a global challenge for many countries. The result of recent researches show promising outcomes regarding all the concerns related to violations of human rights and human dignity. Thus it is important to understand the juridical and social dimension of the subject matter in order to be able to examine its biblical foundation in the light of human rights focusing on the challenges of migration and the crises of refugees. As contextual analysis of the development of the concept, I attempt to evaluate the hermeneutical activities in order to propose a biblical theology based on the concern for refugees. Hence the terminologies like "pilgrims", "foreigners", and "justice" in the Old Testament and the New Testament are crucial for this study.

KEYWORDS: Refugees. Human rights. Foreigners. Justice. Theology

\title{
Introdução
}

\begin{abstract}
A leitura bíblica e construção teológica, como as teologias latino-1-americanas defendem há décadas (STAM, 1984, p. 92-136; PELAEZ et al., 1985, p.145; TABORDA, 1987, p.293-319), precisam dialogar com os desafios contextuais, tornando a vida e seus dilemas lugares privilegiados de releituras da tradição, da práxis pastoral e interpretação das Escrituras. De outra forma, o discurso sobre a fé perderá sua relevância e acabará respondendo a perguntas não feitas. A hermenêutica do mundo da vida ${ }^{1}$, nesse sentido, é fundamental para a teologia bíblica, porque permitirá desenvolver respostas mais complexas e transformadoras: "Quanto mais profundas e completas forem as perguntas que o intérprete trouxer às Escrituras a partir do seu contexto histórico, tanto mais profundas e completas serão as respostas fornecidas pelas Escrituras" (PADILHA, 1984, p. 234). Entre tantas questões, a movimentação migratória, os refugiados e suas implicações políticas, socioculturais e econômicas surgem no cenário mundial como necessário objeto de análise e pesquisas, especialmente por revelar violações de direitos e da dignidade humana. Dessa forma, para ensaiarmos uma leitura bíblica contextualizada aos desafios migratórios e à crise dos refugiados, à luz dos Direitos Humanos, é preciso mapear as discussões históricas, jurídicas e sociais. Somente assim, será possível ajustar os óculos hermenêuticos.
\end{abstract}

\footnotetext{
1 "Mundo da vida" é o reservatório cultural tratado como o lugar (lócus) no qual os sujeitos desenvolvem a interpretação de uma situação e ação compartilhada linguisticamente (HABERMAS, 2002, p. 169-182).
} 
Para tanto, no primeiro momento será analisado historicamente como se deu o tratamento ao estrangeiro em terras brasileiras. Passando de forma resumida por cinco fases, verificaremos a evolução da relação com os imigrantes até a Constituição Federal de 1988. Posteriormente, será apresentado o conceito de refugiado, tal como exposto pela Convenção Relativa ao Estatuto dos Refugiados, de 1951, e por seu Protocolo, de 1967.

Uma vez estabelecidas bases jurídico-sociais da questão, observaremos como a tradição judaico-cristã poderia iluminar a construção teológica a partir dos textos preocupados com a justiça aos mais fragilizados, em especial os estrangeiros e peregrinos, a fim de ensaiar a produção de uma teologia bíblica capaz de lidar com o tema da imigração e refugiados.

\section{$1 \mathrm{Um}$ breve panorama dos refugiados na Constituição Federal e o conceito contemporâneo do termo no direito internacional}

Os estudiosos destacam no Brasil três vertentes que influenciaram a normatividade vigente em cada época referente ao direito dos estrangeiros: (1) a visão tradicional do estrangeiro como elemento estranho à sociedade brasileira e criador de problemas diplomáticos; (2) a visão tradicional do estrangeiro como imigrante, apto a ser integrado por meio de normas de imigração e naturalização; (3) a visão contemporânea, quando o regime jurídico do tratamento ao migrante deve ser visto com base na lógica da gramática dos direitos, sob os auspícios da Constituição Federal de 1988 e dos tratados de direitos humanos. (RAMOS, 2018, p. 910)

As vertentes mencionadas acima são desdobradas em cinco fases. Em cada fase existe um cenário diferente e um tratamento específico para os migrantes. A compreensão de tais momentos históricos é necessária, porque o passado de uma nação é fundamental para compreensão de seu presente. Assim, ainda que de forma resumida, passaremos por cada fase e verificaremos como era compreendido o estrangeiro na terra da Santa Cruz.

A primeira fase remonta ao Brasil Colônia e é denominada de fase do estrangeiro como inimigo. Nessa época, o tratamento com os estrangeiros ficou marcado especificamente pelas atitudes de D. Manoel, que, inspirado pela intolerância religiosa, foi contra a liberdade de credo de judeus e mouros. Foi por ocasião das Ordenações Filipinas que D. Felipe proibiu a entrada nas terras do Reino de ciganos, armênios, árabes, persas e mouriscos de Granada. Casos tais estrangeiros desobedecessem, deveriam ser presos e açoitados. (RAMOS, 2018, p. 910) 
O cenário obteve mudanças tímidas com a chegada da família real ao Brasil. D. João VI através de sua Carta Régia decretou a abertura dos portos às nações amigas e iniciou o tratamento não discriminatório aos estrangeiros, dando os primeiros estímulos à imigração. A timidez do avanço a partir da chegada da família real explica-se pelo fato de a Constituição Imperial (de 1824) apontar uma significativa desconfiança com o estrangeiro. Como explica em detalhes o professor André de Carvalho Ramos:

A desconfiança em face ao estrangeiro era tamanha que o artigo 91, relativo aos direitos políticos, diferenciava o cidadão brasileiro do estrangeiro naturalizado, que era excluído de altos cargos da administração imperial. Nesse sentido, o artigo 136 da Constituição proibia aos estrangeiros naturalizados o exercício de cargo de ministro. Além disso, existiam várias restrições aos estrangeiros expressas em leis infraconstitucionais. Entre elas, havia a impossibilidade de advogar, de requerer habeas corpus, de assumir a direção de um colégio, entre outros, sendo possível a expulsão de estrangeiro nocivo por ato de soberania, sem que houvesse menção a processo administrativo ou decisão judicial. Apesar de tal enfoque discriminatório, o artigo 178, item 6, estabeleceu o direito de qualquer pessoa a determinadas garantias e liberdades, entre elas a liberdade de religião. (2018, p. 911)

A primeira fase, portanto, é marcada pela desconfiança, pelo medo e pelo receio do estrangeiro. A desobediência deste poderia levá-lo ao açoite e à prisão. Apesar do tímido avanço, mesmo sob a Carta Imperial, os estrangeiros continuaram a ser monitorados de perto, sendo tratados com absoluta desigualdade e elevada desconfiança. Nesses termos, o estrangeiro nesse primeiro momento é mais um inimigo que pode causar prejuízos do que especificamente alguém que poderia contribuir de alguma forma para o desenvolvimento do país. Vê-lo como fator de desenvolvimento seria apenas a partir da República, na segunda fase.

A segunda fase compreende o estrangeiro como imigrante e fator de desenvolvimento. A primeira Constituição da República valorizou o estrangeiro como imigrante e fator de desenvolvimento e riqueza. A Carta republicana de 1891 veio repleta do ideal de liberdade e de abolicionismo, assegurando aos brasileiros e estrangeiros residentes direitos fundamentais, especificados no seu artigo 72. Para se ter ideia da diferença de tratamento, o parágrafo 10 do artigo supramencionado, estabelecia o direito de ir e vir no território nacional a todos, mesmo para quem não tinha passaporte. Tal direito foi suprimido pela reforma constitucional de 1926.

A Carta Constitucional de 1891 tinha semelhança muito próxima com a Constituição de 1988, especificamente no que se refere à igualdade entre brasileiros e estrangeiros. O mencionado artigo 72 assegurava a brasileiros e estrangeiros residentes no país a inviolabilidade dos direitos concernentes à liberdade, à segurança individual e à propriedade, considerando que todos são iguais perante a lei. Fica perceptível um significativo avanço 
e um tratamento mais humanitário aos estrangeiros na segunda fase em comparação com a primeira.

A terceira fase vem marcada pelo retrocesso. Lamentavelmente foi a fase do controle e da xenofobia. Como ficou evidente, aquela segunda fase, generosa e igualitária sobre os estrangeiros no Brasil cedeu lugar ao medo e à xenofobia. A mudança radical nessa terceira fase vem contextualizada pela Revolução Russa de 1917 e a Grande Depressão de 1929. Estes dois acontecimentos provocaram preocupação e receio quanto ao recebimento de estrangeiros em terras brasileiras. Como explica o professor da USP, André Ramos, houve um surto nacionalista e aumento da xenofobia, com restrições a entrada de imigrantes mencionada explicitamente no texto constitucional. Vejamos os detalhes da constitucionalização do controle e da xenofobia, explicados pelo professor André:

A entrada do estrangeiro foi pela primeira vez restrita em um texto constitucional, que estabeleceu, em seu artigo 121,6으, que a entrada de imigrantes sofreria restrições necessárias à garantia da integração étnica e capacidade física e civil do imigrante. Ainda dispunha o texto que nenhuma corrente migratória de cada país poderia exceder o limite de dois por cento sobre o número total dos respectivos nacionais já fixados no Brasil durante os últimos cinquenta anos. Estava constitucionalizado o conceito de cotas de imigração. E mais, poderia a União proibir a concentração de imigrantes em qualquer ponto territorial nacional (2018, p. 913).

Verifica-se uma radical mudança na Constituição de 1934 em comparação com a de 1891. Enquanto esta tratava o estrangeiro com generosidade e igualdade, aquela constitucionalizou cotas de imigração, controlando explicitamente não apenas a entrada dos estrangeiros, mas suas atitudes em território nacional. O retrocesso prosseguiu com a Constituição de 1937, aumentando restrições e controles dos estrangeiros. Portanto, a terceira fase foi marcada pelo aumento da xenofobia (tema que será tratado na terceira parte do artigo) e por total controle dos imigrantes em terras brasileiras. Essa fase só terminou após o período da ditadura do Estado Novo e a redemocratização. Essa é fase seguinte.

A quarta fase foi denominada de fase da segurança nacional. Foi nesse período que veio a Constituição de 1946, eliminando os sistemas de cotas de imigração e resgatando a igualdade e garantia de inviolabilidade dos direitos dos brasileiros e estrangeiros residentes. Apesar da retomada de avanços e conquistas, o período foi marcado também por algumas restrições mais específicas no âmbito nacional. Contudo, deve-se dizer que os avanços e conquistas resgatados eram ainda caracterizados por certa timidez, especificamente no sentido de garantias fundamentais.

As Constituições de 1967 e 1969 voltaram a tratar o tema dos estrangeiros de forma genérica, não avançando significativamente. Com a redução da 
perda do fluxo migratório, o tema passou a não desfrutar de lugar privilegiado na agenda política. Como lembra o professor André Ramos, foi no regime militar, no ano de 1980, que foi editado a Lei n. 6.815/80 que tratava da situação jurídica dos estrangeiros no Brasil (RAMOS, 2018, p. 914). É curioso o fato de a lei ter sido aprovada por decurso de prazo (sem maior análise por parte do Congresso). O mais intrigante é que essa lei só veio a ser revogada 37 anos depois, especificamente em 2017, quase 30 anos após a Constituição Federal de 1988, quando foi editada a Lei 13.445 (a nova Lei de Migração).

A quinta e última fase marca definitivamente a fase da igualdade e garantia. Conhecida como Constituição cidadã, a Carta Magna de 1988 num profundo espírito de respeito à dignidade humana garantiu a inviolabilidade do direito à vida, à liberdade, à igualdade, à segurança e à propriedade (artigo 5o caput). As garantias fundamentais estabelecidas na Carta constitucional de 1988 foram relevantes para conquistas futuras no tratamento com os estrangeiros. O professor André Ramos explica os avanços a partir de 1988:

De início, a CF/88 limitou ao "estrangeiro residente" a titularidade de direitos fundamentais. Ocorre que tal restrição ofende aos princípios basilares de um Estado Democrático de Direito (art. $1^{\circ}$ ), pois permitiria a privação do direito à vida ou integridade física do turista, por exemplo. Como visto, é pacífica na doutrina a extensão da titularidade de direitos fundamentais a todos os estrangeiros. Tal extensão justifica-se de diversos modos: (i) o Estado Democrático de Direito, previsto no artigo $1^{\circ}$ da $\mathrm{CF} / 88$, não admite a privação de direitos com base no critério da "não residência", que não possui qualquer pertinência com o exercício de tais direitos básicos; (ii) tratar os estrangeiros não residentes como desprovidos de direitos ofende um dos fundamentos da república, que é a promoção da dignidade humana (artigo $1^{\circ}$ inciso III); (iii) o reconhecimento pela $\mathrm{CF} / 88$ dos direitos decorrentes dos tratados internacionais de direitos humanos (art. $5^{\circ}$ parágrafo $2^{\circ}$ ) já ratificados pelo Brasil permite deduzir que tais tratados, como o Pacto Internacional de Direitos Civis e Políticos ou a Convenção Americana de Direitos Humanos, estendem a todos, estrangeiros residentes ou não, a titularidade de direitos humanos. (RAMOS, 2018, p. 914)

Como explicado pelo professor André de Carvalho Ramos, a extensão das garantias fundamentais para os estrangeiros, encontra base sólida na Constituição de 1988. Se no passado os estrangeiros foram tratados como inimigo e considerados um perigo para o país, com a Constituição vigente, os estrangeiros são cidadãos e cidadãs de direitos, que desfrutam de igualdade ampla, generosidade e solidariedade. Os avanços no tratamento jurídico com os estrangeiros são relevantes ainda no fortalecimento do Estado Democrático de Direito. Se no passado os estrangeiros deveriam ser monitorados e vigiados, pois ameaçavam a segurança nacional, no presente, a partir da Carta Maior, o acolhimento, cuidado e garantias fundamentais aos estrangeiros significam sólido compromisso com a democracia e prática 
fundamental na construção de uma sociedade alicerçada na igualdade, na justiça e na solidariedade.

O direito dos refugiados é regulado pelo direito internacional público e pelo direito interno de vários Estados. No caso específico do Brasil, o direito dos refugiados foi disciplinado pela Lei 9.474 de julho de 1997. Como lembra o professor internacionalista Valério Mazzuoli, "o instituto jurídico do refúgio tem suas normas elaboradas por uma organização (de alcance global) de fundamental importância vinculada às Nações Unidas: o Alto Comissariado das Nações Unidas para Refugiados - ACNUR". (MAZZUOLI, 2017, p. 386). Esta organização, como lembra o professor Mazzuoli (2017, p. 386), tem oferecido auxílio e proteção a milhares de refugiados ao redor do mundo, encontrando soluções duradouras para muitos deles. Mas, afinal, como o direito internacional dos direitos humanos define o refugiado? Como se sabe, os direitos dos refugiados estão consagrados em dois textos magnos: na Convenção Relativa ao Estatuto dos Refugiados, de 1951 e no seu Protocolo de 1967.

Toda pessoa que, temendo ser perseguida por motivos de raça, religião, nacionalidade, grupo social ou opiniões políticas, se encontra fora do país de sua nacionalidade e que não pode ou, em virtude desse temor, não quer valer-se da proteção desse país, ou que, se não tem nacionalidade e se encontra fora do país no qual tinha sua residência habitual, não pode ou, devido ao referido temor, não quer voltar a ele. (MAZZUOLLI, 2017, p. 387)

Como fica perceptível, a concessão do status de refugiado dá-se em virtude de perseguição motivada por raça, religião, nacionalidade ou mesmo pelo fato da pessoa pertencer a um determinado grupo social e ser detentor de uma opinião política. $\mathrm{O}$ conceito de refugiado supramencionado é aquele compreendido na perspectiva do direito internacional. Contudo, no âmbito nacional, foi a Lei 9.474 de 22 de julho de 1997 que definiu os mecanismos para implementação do Estatuto dos Refugiados de 1951. Na Lei brasileira, é reconhecido como refugiado todo indivíduo que:

I - devido a fundados temores de perseguição por motivos de raça, religião, nacionalidade, grupo social ou opiniões políticas encontra-se fora de seu país; II - não tendo nacionalidade e estando fora do país onde antes teve sua residência habitual, não possa ou não queira regressar a ele, em função das circunstâncias descritas no inciso anterior;

III - devido a grave e generalizada violação de direitos humanos, é obrigado a deixar seu país de nacionalidade para buscar refúgio em outro país. (LEI 9.474, artigo $1^{\mathrm{O}}$ )

É explícito o diálogo entre os textos em sentido global e a legislação brasileira. Ademais, digno de destaque é a menção "a grave e generalizada violação dos direitos humanos" (LEI 9.474, 10, III). O legislador mostra-se preocupado com a violação dos direitos humanos, que cresce de forma 
desenfreada, atingindo o núcleo fundamental da vida - a dignidade. Portanto, o diálogo entre os instrumentos tem o objetivo de proteger o ser humano que solicita o refúgio. Percebe-se que o direito internacional dos direitos humanos está em profunda consonância com a legislação nacional. Isso não significa que não possa e que não vá haver conflitos. No entanto, está sólida a tese de que na hipótese de conflito entre as normas internacionais e locais, em matéria de direitos humanos, deverá prevalecer sempre a norma mais favorável ao sujeito de direito. Como ensina o professor Fábio Konder Comparato: a proteção da dignidade da pessoa humana é a finalidade última e a razão de ser de todo o sistema jurídico. (2017, p. 76)

\section{O lugar dos direitos humanos na Constituição Federal $e$ sua relação com os refugiados}

Nesse segundo tópico será apresentado o lugar dos direitos humanos na Constituição Federal e no Direito Internacional e sua relação com os refugiados. O objetivo é demonstrar que os direitos humanos desfrutam de um lugar privilegiado na Constituição Federal e que justamente por essa razão estão estreitamente relacionados com a dignidade humana dos refugiados.

O tema dos refugiados ganhou atenção especificamente no direito internacional a partir da década de 1920, em virtude dos acontecimentos do pós-Primeira Guerra. Contudo, a atenção para o tema vai intensificar após a Segunda Guerra Mundial. Deve-se registrar dois aspectos que distinguem a Primeira da Segunda Guerra Mundial: o número de mortos e o número de refugiados. Enquanto na Primeira Guerra Mundial morreram aproximadamente 9 milhões de pessoas, sendo quase a totalidade de militares, na Segunda Guerra Mundial, calcula-se que 60 milhões de pessoas foram mortas, a maior parte delas civis. Quanto aos refugiados por ocasião das duas Guerras: na Primeira, aproximadamente 4 milhões; na Segunda eram mais de 40 milhões. A partir desses acontecimentos "as consciências se abriram, enfim, para o fato de que a sobrevivência da humanidade exigia a colaboração de todos os povos, na reorganização das relações internacionais". (COMPARATO, 2017, p. 226)

Nesse contexto, é significativo enfatizar que no Brasil os direitos humanos e o asilo político são princípios constitutivos nas relações internacionais. Em virtude de sua importância, o texto constitucional do artigo $4^{\circ}$ (com exceção do parágrafo único) deve ser citado integralmente:

A República Federativa do Brasil rege-se nas suas relações internacionais pelos seguintes princípios: 
I - independência nacional

II - prevalência dos direitos humanos

III - autodeterminação dos povos

IV - não intervenção

$\mathrm{V}$ - igualdade entre os Estados

VI - defesa da paz

VII - solução pacífica dos conflitos

VIII - repúdio ao terrorismo e ao racismo

IX - cooperação entre os povos para o progresso da humanidade

X - concessão de asilo político. (CONSTITUIÇÃO DA REPÚBLICA FEDERATIVA DO BRASIL, 2017, p. 3)

Como orienta a Carta Maior, o Estado brasileiro rege-se nas suas relações internacionais a partir de dez princípios fundamentais. Absolutamente relacionados com essa pesquisa, os princípios da prevalência dos direitos humanos, defesa da paz, solução pacífica dos conflitos, cooperação entre os povos para o progresso da humanidade e concessão de asilo político são elementos fundamentais para compreender o lugar da migração no direito constitucional brasileiro e nos direitos humanos.

A Constituição Federal de 1988 marca a passagem de um Estado autoritário e de exceção para um Estado Democrático de Direito. Nesse contexto, a dignidade da pessoa humana deixa de ser algo irrelevante e insignificativo e passa a ser fundamento do Estado Democrático de Direito (artigo 1ํㅡㄴ, III, da Constituição). A dignidade humana aparece como núcleo básico e informador de todo ordenamento jurídico, impondo-se como fundamento dos direitos humanos. Logo após o constituinte mencionar o princípio da independência nacional, a prevalência dos direitos humanos é destacada de forma extraordinária e inédita como princípio a reger o Brasil no plano internacional. Como leciona a professora Flávia Piovesan:

A constituição de 1988 introduz inovações extraordinárias no plano das relações internacionais. Por um lado, reitera a antiga preocupação vivida no Império no que se refere à independência nacional e à não intervenção, endossando ainda os ideais republicanos voltados à defesa da paz e à solução pacífica das controvérsias. Contudo, por outro lado, inova ao realçar uma orientação internacionalista jamais vista na história constitucional brasileira. A orientação internacionalista se traduz nos princípios da prevalência dos direitos humanos, da autodeterminação dos povos, do repúdio ao terrorismo e ao racismo, da cooperação entre os povos para o progresso da humanidade e da concessão de asilo político, nos termos do artigo $4^{\circ}$, incisos II, III, VIII, IX e X. (2013, p. 155)

Fica perceptível na lição da professora Piovesan, que houve um avanço fundamental na Constituição Federal de 1988, especificamente no que se refere ao lugar dos direitos humanos. Estes, não estão mais esquecidos, relegados a lugares periféricos, mas encontram-se como elementos nortea- 
dores das relações entre o Brasil e outros países. A prevalência dos direitos humanos, como princípio fundamental que rege as relações internacionais, aponta para um Estado que definitivamente decidiu deixar para a trás a barbárie e o retrocesso e avançar em direção à civilização e ao progresso, onde o ser humano não é meio, mas fim em si mesmo.

Dessa forma, os princípios elencados no artigo $4^{\mathrm{o}}$ da Constituição Federal dialogam entre si no sentido de garantir a dignidade humana de cada cidadão. E nesse contexto, insere-se o migrante, o refugiado, o estrangeiro residente, que tem expressamente garantido, pela Constituição Federal, "a inviolabilidade do direito à vida, a liberdade, à igualdade, à segurança e à propriedade" (artigo 5o, caput). Aqui, é possível dizer que a Constituição Federal tem um sensível e sólido sentimento de hospitalidade e de acolhimento no que se refere aos refugiados. Estes, devem ser tratados com a mesma igualdade dos brasileiros, tendo os mesmos direitos garantidos. Sem diminuir a soberania nacional, o tratamento igualitário garantido aos estrangeiros residentes promove positivamente a democracia brasileira e coloca o país num lugar de destaque entre as grandes civilizações.

A Assembleia Geral das Nações Unidas (ONU), em 19 de setembro de 2016, adotou a Declaração de Nova York para aprimorar a proteção de refugiados e migrantes. A Declaração foi adotada de forma consensual por 193 Estados membros da ONU. Considerando o relevante aumento dos fluxos de pessoas em todo o globo nas últimas décadas, os Estados adotaram diversos compromissos e apontaram inúmeros outros desafios para o futuro. O professor de Direitos Humanos da USP, André de Carvalho Ramos, ao comentar a Declaração de Nova York, destaca sete compromissos adotados pelos Estados membros da ONU:

1 - proteger os direitos humanos de todos os refugiados e migrantes, não importando o estatuto migratório, respeitando a Declaração Universal dos Direitos Humanos e demais tratados internacionais;

2 - condenar a discriminação contra os refugiados e migrantes, e reconhecer que a diversidade fortalece e enriquece toda sociedade, devendo ser impedida a xenofobia, intolerância, racismo e tratamentos discriminatórios;

3 - assegurar a cooperação internacional para que um Estado não tenha que lidar, isoladamente, com esses fluxos de pessoas. A responsabilidade pelo acolhimento aos refugiados e migrantes deve ser compartilhada;

4 - as crianças refugiadas e migrantes devem ter tratamento adequado ao seu melhor interesse e ter direito à educação, com base na Convenção da ONU sobre os Direitos das Crianças;

5 - adotar medidas para prevenir e reprimir a violência sexual e baseada em gênero dos migrantes e refugiados;

6 - fortalecer o acolhimento dos refugiados, com base em redesenho das responsabilidades dos Estados, sociedade civil e agências da ONU, em especial o Alto Comissariado das Nações Unidas para os Refugiados (ACNUR); 
7 - fortalecer a governança global da migração, pela inserção da Organização Internacional de Migrações como agência especializada da ONU. (RAMOS, 2018, p. 187)

Ao observar os compromissos da Declaração de Nova York sintetizados pelo professor André de Carvalho Ramos, é possível compreender a riqueza e profundidade do documento, que, embora seja de natureza soft law (sem força vinculante), possui significativa importância, especialmente no aspecto hermenêutico dos tratados internacionais de direitos humanos que podem incidir diretamente sobre os refugiados e migrantes. O Brasil, na medida em que ratificou os tratados internacionais pode se apropriar da Declaração de Nova York, tendo a mesma orientação na interpretação dos comandos desses tratados.

O pacto pela defesa dos direitos humanos dos refugiados e migrantes é decisivamente um pacto global e não apenas local, devendo ser respeitado e praticado pelo Brasil. Trata-se de um pacto fundamentado juridicamente, no sentido de proteger a dignidade humana da pessoa, nos termos do artigo $1^{\underline{0}}-$ III, e $4^{\mathrm{o}}-X$, da Constituição Federal, artigo XIV da Declaração Universal dos Direitos Humanos, da Convenção Relativa ao Estatuto dos Refugiados, de 1951 e o seu Protocolo de 1967 e pela Lei 9.474 de Julho de 1997.

O lugar dos direitos humanos na Constituição Federal está em sintonia com um dos fundamentos do Estado Democrático de Direito, o da promoção dos direitos humanos. Nesse sentido, verifica-se uma relação estreita entre direitos humanos e refugiados. Tal premissa justifica-se na medida em que a perseguição a uma pessoa caracteriza grave violação aos direitos humanos. Nessa linha de argumentação, a professora Flávia Piovesan foi assertiva ao dizer que:

Cada solicitação de asilo é resultado de um forte padrão de violência a direitos universalmente garantidos. Quando pessoas têm que abandonar seus lares para escapar de uma perseguição, toda uma série de direitos humanos é violada, inclusive o direito à vida, liberdade e segurança pessoal, o direito de não ser submetido a tortura, o direito à privacidade e à vida familiar, o direito à liberdade de movimento e residência e o direito de não ser submetido a exílio arbitrário. Os refugiados abandonam tudo em troca de um futuro incerto em uma terra desconhecida. É assim necessário que as pessoas que sofram esta grave violação aos direitos humanos possam ser acolhidas em um lugar seguro, recebendo proteção efetiva contra a devolução forçosa ao país em que a perseguição ocorre e tenham garantido ao menos um nível mínimo de dignidade. (2018, p. 257)

A relação entre direitos humanos e refugiados é perceptível a partir do argumento da professora Piovesan. Toda solicitação de asilo é consequência do flagrante desrespeito aos direitos humanos fundamentais. Ao abandonar o seu lar de origem e buscar proteção, liberdade e segurança, o refugiado 
não está em busca de privilégios e tão pouco procurando ocupar o lugar de trabalho de outra pessoa. Ele foi vítima da violação de garantias e direitos que lhe são fundamentais. Cada refugiado tem sua própria história, geralmente marcada por abusos, repressão, temor e medo. Uma situação que exemplifica bem essa relação entre refugiados e direitos humanos é o recente caso (janeiro de 2019) da jovem saudita de 18 anos que, por renunciar ao Islã, estava sendo ameaçada de morte pela família. Rahaf Mohammed al-Qunun fugiu da sua família, se trancou no quarto de um hotel na Tailândia e pediu ajuda pelo Twitter. Ela passou a ficar sob os cuidados do Alto Comissariado da ONU para os Refugiados (Acnur). A perseguição religiosa da qual foi vítima a jovem constitui absoluta violação dos direitos fundamentais e por essa razão, a jovem ganhou status de refugiada pela Organização das Nações Unidas (ONU). ${ }^{2}$

A proteção dos refugiados opera a partir da estrutura de direitos individuais e responsabilidade estatal que é oriunda da mesma base filosófica que a proteção internacional dos direitos humanos. Nesse sentido, o Direito Internacional dos Direitos Humanos é a fonte dos princípios de proteção dos refugiados. É perceptível a relação entre a Convenção de 1951 e a Declaração Universal de 1948, especificamente o seu artigo 14. Assim, é "impossível conceber o Direito Internacional dos Refugiados de maneira independente e desvinculada do Direito Internacional dos Direitos Humanos" (PIOVESAN, 2018, p. 262). Essa relação entre os instrumentos nacionais e internacionais busca sempre defender e garantir a dignidade integral do ser humano. Portanto, é necessário insistir: a problemática dos refugiados deve ser enfrentada sob a perspectiva dos direitos humanos.

A fim de evidenciar esse encontro entre direitos humanos e refugiados, demonstrando a relação estreita que existe entre eles, destacam-se quatro momentos fundamentais onde acontece de forma explícita essa dinâmica. O primeiro momento é anterior ao refúgio, quando acontece a ameaça de violação ou a efetiva violação a direitos fundamentais, levando a pessoa a solicitar o refúgio. A professora Piovesan explica que "a violação e o colapso do Estado de Direito, a violência, os conflitos internos e a limpeza étnica constituem as causas principais que levam à solicitação de refúgio" (PIOVESAN, 2018, p. 266). Nessa primeira fase, a partir da Declaração Universal dos Direitos Humanos de 1948, os seguintes direitos devem ser respeitados: o direito à igualdade e à não discriminação (art. $3^{\circ}$ ); o direito à vida, à liberdade e à segurança pessoal (art. $3^{\mathrm{o}}$ ); o direito à igualdade perante a lei (arts. $6^{\circ}, 7^{\circ}, 8^{\circ}, 10^{\circ}$ e $\left.11^{\circ}\right)$; o direito a não ser submetido à tortura ou a tratamento cruel, desumano ou degradante (art. $5^{\circ}$ ); a proteção

\footnotetext{
${ }^{2}$ G1.COM. Jovem saudita que fugiu da família ganha status de refugiada. Disponível em: <https:// g1.globo.com/mundo/noticia/2019/01/09/jovem-saudita-que-fugiu-da-familia-ganha-status-de-refugiada.ghtml>. Acesso em: 10 jan. de 2019.
} 
contra interferência arbitrária na privacidade, na família ou no domicílio

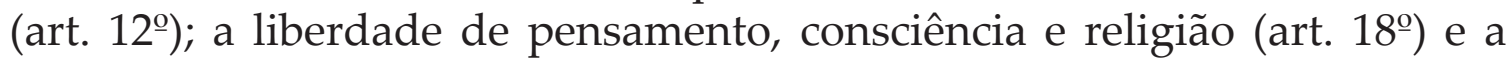
liberdade de opinião e expressão (art. 19º) (PIOVESAN, 2018, p. 266). Nota-se nessa fase que antecede ao refúgio uma série de direitos estabelecidos na Declaração de 1948 que devem ser observados de forma irrestrita.

A inobservância dos direitos supramencionados na primeira fase provoca um segundo momento, onde é verificável a relação entre direitos humanos e refugiados. Esse momento ocorre quando a pessoa é obrigada a abandonar seu país de origem, devido a fundados temores de perseguição por motivos de raça, religião, nacionalidade, por pertencer a um determinado grupo social, ou mesmo por opiniões políticas. Trata-se de um momento delicado, pois nesse período o refugiado vai em busca de proteção e acaba se expondo a outros tipos de violações nos países onde chega. Nesse momento, destaca a professora Piovesan: "mulheres e crianças estão particularmente vulneráveis e frequentemente são vítimas de abusos e exploração sexual. Esse ainda é o momento no qual as famílias são separadas" (PIOVESAN, 2018, p. 267). Nesse contexto, a Declaração de 1948 determina a observância dos seguintes direitos: a proteção contra a prisão, detenção ou exílio ilegal (art. 9o); a liberdade de movimento e o direito de deixar qualquer país (art. 13); o direito de solicitar e gozar de asilo em outro país, em razão de perseguição (art. 14); o reconhecimento de que a família é a base natural e fundamental da sociedade, merecendo proteção (art. 16); o direito à vida, à liberdade e à segurança pessoal (art. $3^{\circ}$ ); e o direito a não ser submetido a tortura, a tratamento cruel, desumano ou degradante (art. 5ㅇ). (PIOVESAN, 2018, p. 267).

O terceiro momento é o período específico do refúgio. O país que acolheu o refugiado deve garantir os seus direitos e o refugiado, por sua vez, deve respeitar as leis do país que o acolheu. Nesse período, os direitos estabelecidos pela Convenção de 1951, tais como o direito de não sofrer discriminação, direito à liberdade religiosa, aquisição de propriedade, livre acesso ao poder judiciário, direito ao trabalho, etc. devem ser garantidos pelo País aos estrangeiros. Deve-se destacar ainda o direito basilar do sistema de proteção aos refugiados, a saber, o direito de não ser repatriado. Tal direito está consagrando no artigo 33 da Convenção de 1951 e fundamentado no princípio da não devolução. Afirma o artigo 33: "nenhum dos Estados-contratantes expulsará ou repelirá um refugiado, seja de que maneira for, para as fronteiras dos territórios onde a sua vida ou a sua liberdade sejam ameaçadas" (PIOVESAN, 2018, p. 270). Nesse momento, de um lado o país que acolheu o refugiado garante a ele todos os seus direitos. E do outro lado, o refugiado respeita todas as leis do país que o acolheu.

O quarto e último momento é quando existe a solução para o problema dos refugiados. Nesse contexto, destaca-se a repatriação voluntária de 
refugiados, a integração local e o reassentamento em outros países. Como explica a professora Flávia, "o processo de integração no país de origem ou o processo de integração no novo país apresenta uma nova série peculiar de problemas" (2018, p. 270). Nesse aspecto, a Declaração Universal de Direitos Humanos garante direitos fundamentais, como o direito de regressar ao país de origem, o direito à nacionalidade, o direito a não discriminação, os direitos econômicos, sociais e culturais indispensáveis à sua dignidade e ao livre desenvolvimento de sua personalidade, o direito ao padrão de vida digno, entre outros (PIOVESAN, 2018, p. 270). A relação entre direitos humanos e refugiados é absolutamente evidente, não sendo possível falar em direito dos refugiados de maneira independente dos direitos humanos.

Depois desse arrazoado, temos o locus de discussão, sendo possível aproximarmos os óculos hermenêuticos cuja proposta seria pensar a teologia bíblica como resposta e diálogo sobre o tema. Em síntese, (1) não é possível pensar o tema "refugiado" sem relacioná-lo ao conceito de justiça, que desde as discussões internacionais garantem direitos e exigem deveres às nações; (2) a solidariedade perpassa a discussão, porque tornam as nações coparticipantes das necessidades dos refugiados; (3) o tema exige um pacto global.

\section{Teologia da Justiça e os Direitos Humanos dos Refugiados}

Desenvolvendo a genealogia da moderna discussão dos direitos humanos, cujas bases se estabelecem no conceito da "dignidade humana", o jurista Konder Comparato fala a respeito das tradições judaica e grega. Segundo sua descrição,

a respeito da dignidade humana, o pensamento ocidental é herdeiro de duas tradições parcialmente antagônicas: a judaica e a grega. A grande (e única) invenção do povo da Bíblia, uma das maiores, aliás, de toda a história humana, foi a idéia da criação do mundo por um Deus único e transcendente. Os deuses antigos, de certa forma, faziam parte do mundo, como super-homens. Iahweh, muito ao contrário, como criador de tudo o que existe, é anterior e superior ao mundo [...]. (2019, p. 8)

O mesmo autor acrescenta que a ideia de criação do homem à imagem e semelhança de Deus penetrou a cultura ocidental tornando a sacralidade da vida parte constituinte dos principais movimentos humanistas. (2019, p. 13). Por isso, a história da recepção da tradição judaico-cristã mostrou a influência das Escrituras na formatação da afirmação teológico-filosófica do humano como sujeito de direitos. Por essa razão, Jean Rivero e Hugues Moutouh podem afirmar a íntima relação dos Direitos Humanos e a tradição judaico-cristã: 
[...] a própria noção de direitos do homem supõe uma civilização em que a dignidade da pessoa humana se mostra em evidência [...] o cristianismo, nesse ponto herdeiro da tradição judaica enriquecida e renovada, deu-lhe os fundamentos que progressivamente a impuseram (2006, p. 37).

Por outro lado, segundo os historiadores jurídicos, a maneira como a Reforma (e seus movimentos corolários) interpretou a Bíblia foi responsável tanto para o desenvolvimento da Modernidade como das discussões iniciais do que seria o "jusnaturalismo" (ideia desenvolvida no direito moderno sobre direitos naturais e universais, que estão nas bases dos Direitos Humanos):

Ainda que, de um lado, inúmeros teóricos admitam certa dificuldade em assinalar pontos de interação entre a Reforma e o Humanismo Renascentista, por outro, não se pode deixar de reconhecer a influência do protestantismo na gênese do Capitalismo moderno, na formulação da mentalidade livre individualista, na valoração da consciência moral, na contribuição da filosofia dos direitos humanos e, fundamentalmente, no impulso para a moderna concepção de jusnaturalismo (WOLKMER, 2005, p. 21).

A leitura bíblica na Reforma, como também nos discursos oficiais católicos, defende a justiça, a inviolabilidade dos direitos da pessoa humana e a integralidade da criação como fundamentais na indicação do Reino e conteúdo indispensável da proclamação do Evangelho. E como nos mostram os documentos internacionais sobre o tema, o direito dos refugiados precisa ser observado à luz dos direitos humanos. Conseguintemente, esta questão precisa ser tratada, também, sendo fiel aos seus pressupostos judaico-cristãos, a partir da hermenêutica bíblica. Por isso, a análise bíblico-semântica relacionada ao sintagma "justiça" nos ajudará no trabalho.

Na Bíblia Hebraica, o termo "justiça" refere-se a três principais substan-

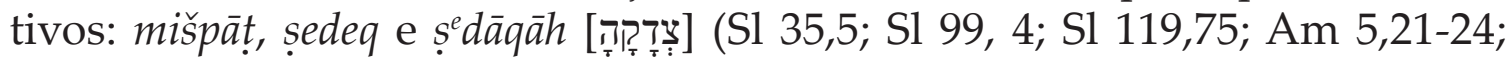
Os 10,12; Os 12,6; Is 1, 10-17). Mesmo que mišpāt e ședeq sejam termos muito próximos, há algumas nuances etimológicas e semânticas. Sedeq refere-se a práticas sociais, comportamento socialmente apropriado à luz do modelo do Javé justo. (JENNI; WESTERMANN, 2004, p. 1310) H. H. Schmid estende o sentido colocando-o ao lado do conceito "ordem", no contexto do Oriente Próximo, cujo conteúdo descreve o cosmos, a ordenação do mundo que existe desde a criação - tendo as cosmogonias como modelo. Esse horizonte semântico se manifesta em reinos, leis, sabedoria, natureza, fertilidade, pois o Deus ordenador garante a ordem e instala o rei como seu representante na terra, e cada indivíduo deve participar dessa ordenação agindo sob a orientação do Javé criador/ordenador. (JENNI; WESTERMANN, 2004, p. 1311). É nesse sentido que o salmista fala do Deus que concede o juízo ao rei (Sl 72, 1-2). Assim, os atentados contra a justiça são entendidos como perturbação à ordem cósmica, que só poderia ser restaurada pelo perdão de Deus, não enquanto credor severo que põe em ordem dívidas, mas enquanto criador que recoloca o ser humano na 
sua condição de "ser-amado" por Ele e que repara os danos causados ao cosmo (VAZ, 2012, p. 64).

As três palavras mišpăț ședeq e ședāqāh aparecem frequentemente em contexto de justiça salvadora, que inclui uma acção de amor gratuito e de misericórdia benfeitora. É importante notar que as três palavras aparecem frequentemente em paralelo com conceitos associados à aliança de Deus com Israel, como hesed ("bondade, misericórdia, amor") e 'emet ("verdade, fidelidade"). Estas ligações fazem sobressair em mišpāț, ședeq e ședāqāh o sentido de uma atitude de bondade social ativa, sempre disposta a atender à necessidade do outro e a promover o seu bem: apontam para uma bondade generosa, fiável e fiel. Portanto, o seu significado vai para além da justiça estrita; é uma justiça libertadora; refere-se ao melhoramento das condições do necessitado na sociedade, melhoramento que, no plano do governo, se manifesta por medidas legais, adequadas ao fim em vista. (VAZ, 2012, p. 64-65)

Justiça de Deus na Bíblia Hebraica não tem característica forense, mas segue a ideia de ordenação e construção de sustento das relações através das quais os grupos mais fragilizados são acolhidos, protegidos, assistidos, ou seja, justificados. Em vários lugares, encontramos a lista dos grupos mais dependentes da aplicação desse modelo libertador e restaurador de justiça: estrangeiro, órfão e viúva (Dt 27,19; Ex 22,1920; Lv 19,33-34). Os termos usados para "estrangeiro" ou "forasteiro" são ger, zar ou nakri. Holladay e Köhler explicam que ger é aquele que, sozinho ou com sua família, afastou-se de seu povo ou tribo por causa da guerra $(2 \mathrm{Sm} 4,3)$, fome (Rt 1,1$)$, peste ou culpa de sangue, o qual procura abrigo e acolhimento quando seu direito de posse de terra, casamento e participação nas questões judiciais inevitavelmente são reduzidos. (HOLLADAY; KÖHLER, 2000, p. 126) O nakri ou nekar pode ser traduzido por "estrangeiro", "de terra estrangeira" (Dt 31,16). Há outras expressões: admat nekar (solo estrangeiro [Sl 137,4]), ben-nekar (filho do estrangeiro [Gn 17,12; 2Sm 22,45]). (HOLLADAY; KÖHLER, 2000, p. 238)

Nos códigos legais, ${ }^{3}$ desenvolve-se a solidariedade com os estrangeiros a partir do modelo da condição transeunte de Israel. Para a tradição bíblica, ser peregrino é a condição do povo de Deus que, por vezes, era afastado de sua pátria, tendo como paradigma Abraão e os patriarcas (Gn 12,1), como, também, os estrangeiros que habitavam entre o povo. Para esse segundo horizonte, José Adriano explica:

Por outro lado, descreve os estrangeiros que viviam entre os israelitas, como o cananeu residente em Israel ou fugitivos procedentes do derrotado reino do

\footnotetext{
${ }^{3}$ Código da Aliança (Ex 20,22-23,33), Lei Deuteronômica (Dt 12-26) e Código da Santidade (17-26) são conjuntos legais desenvolvidos na história de Israel-Judá. O Código da Aliança foi o primeiro grupo de leis relidas e estendidas pelo Deuteronômio e, por sua vez, usada e reestruturado pelo Código Sacerdotal (CRÜSEMANN, 2001).
} 
norte, frequentemente mencionados junto a órfãos, viúvas e pobres, grupos fragilizados que mereceriam tratamento especial, justamente por lhes faltarem os meios de subsistência. Nesse sentido, fala-se de estrangeiro, hóspede, imigrante, cativo, exilado, estranho, alheio ou até escravo, tanto de maneira individual como coletiva, destacando sempre o necessitado, o pobre e o desprotegido, que necessitavam ser assistidos em suas necessidades. (ADRIANO FILHO, 2001, p. 23)

No Código da Aliança, o direito se estabelece a partir do conceito do Deus compassivo (Ex 22,6), cuja ação é resultado do clamor do povo, que O leva a reivindicar a justiça segundo o modelo da compaixão pelos necessitados. Como defendem os códigos legais em Israel, a compaixão de Deus serve de modelo para a ação do seu povo e, uma vez coparticipantes dessa mesma condição, exige-se a solidariedade aos estrangeiros.

\begin{tabular}{|c|c|}
\hline 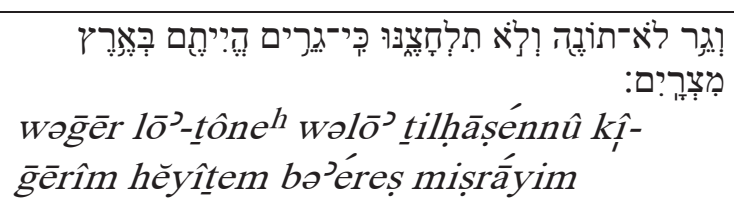 & $\begin{array}{l}\text { E ao estrangeiro não afligirá, nem o } \\
\text { oprimirás; pois forasteiro foi na terra do } \\
\text { Egito. }\end{array}$ \\
\hline 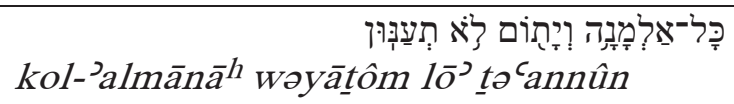 & Toda viúva e órfão não oprimireis \\
\hline 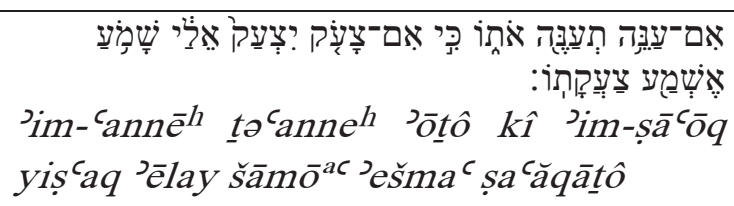 & $\begin{array}{l}\text { se o oprimir afligindo a ele, clamará a } \\
\text { mim, escutar escutarei o clamor dele } \\
\text { escutarei }\end{array}$ \\
\hline 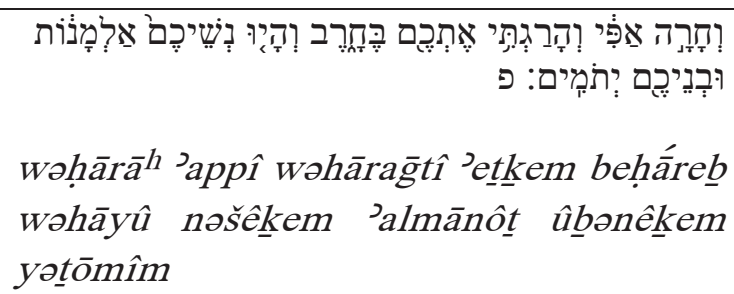 & $\begin{array}{l}\text { e se inflamará a minha fúria e a vós [eu] } \\
\text { matarei com espada; vossas mulheres } \\
\text { ficarão viúvas e vossos filhos, órfãos. }\end{array}$ \\
\hline
\end{tabular}

A importância desse texto pode ser percebida com suas tantas reiterações na literatura bíblica (Ex 23,9; Lv 19,33-34; Dt 10,18-19; Dt 27,19; Jr 7,6; Jr 22,3; Zc 7,9-10). Os verbos "afligir"(ינה) e "oprimir/atormentar" (לחץ) aumentam o rigor da proibição. Segundo a Mishnah Bava Metsia, eles poderiam significar vitimização ou defraudação (SARNA, 1991, p. 137). Novamente, encontramos viúvas, órfãos e estrangeiros como grupos protegidos por Deus e para os quais se exige a mesma consideração por parte daqueles e daquelas que são responsáveis pela realização do estabelecimento da justiça, cujo modelo encontra-se em Javé. No Código da Santidade, relendo a tradição legal sobre os estrangeiros, estende-se 
o auxílio e compreensão teológica, e defende-se o cuidado ao ger como se ele pertencesse ao próprio povo:

E quando peregrinar um estrangeiro (ger) na vossa terra não o oprimireis, como nativo entre vós será o estrangeiros que peregrina convosco e o amará como a ti mesmo, porque peregrino fostes na terra do Egito. Eu sou Javé o vosso Deus. (Lv 19, 33-34)

Essa exigência ecoa o paralelismo de Lv 19, 17-18 que exorta a não se vingar ou guardar rancor contra os membros do povo, os quais são o "próximo"

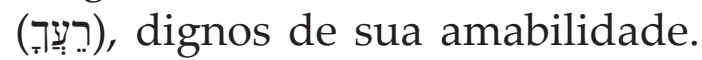

Na tradição profética há denúncias contra a violação desse direito identificado como "pobre", mas que na tradição bíblica se aplica a todas as categorias acima citadas (Is 1,17; Is 3,14-15; Is 10, 2; Jr 5,28; Ez 16,49; Ez 18, 17; Ez 22,7; Am 8,4; Ml 3,5). Inclusive, em Ez 16,49 a tradição da hospitalidade ( $\mathrm{Lv} 25,35)$ é relida para avaliar Gn $19^{4}$ :

\begin{tabular}{|c|c|}
\hline 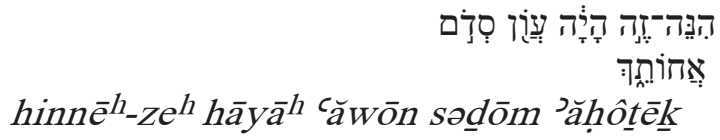 & $\begin{array}{l}\text { Eis que esta foi a iniquidade de Sodoma, } \\
\text { tua irmã: }\end{array}$ \\
\hline 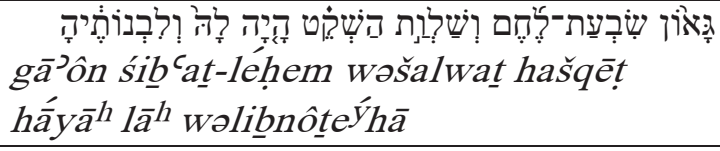 & $\begin{array}{l}\text { exaltação, satisfação de pão e facilidade } \\
\text { descuidada teve ela e suas filhas; }\end{array}$ \\
\hline 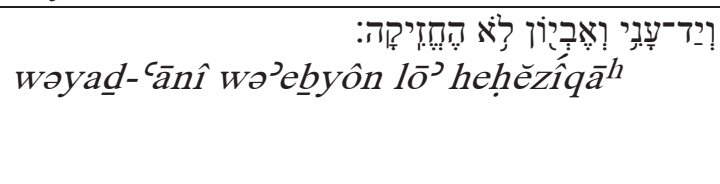 & $\begin{array}{l}\text { e ao pobre e necessitado não estendeu a } \\
\text { mão. } \\
(\text { Ez } 16,49)\end{array}$ \\
\hline
\end{tabular}

O profeta Ezequiel desenvolve a percepção de que Jerusalém é pior do que Samaria, o que permite justificar, desviar a punição "das suas irmãs" (16,51-52). Para o profeta, à luz da tradição dos hospedes de Ló, a falta de solidariedade, mesmo com fartura de comida, demonstrou ser o grande pecado de Sodoma ${ }^{5}$. Em Is 1,10-20, o mesmo adjetivo é aplicado aos líderes de Jerusalém que precisam ser repreendidos por não promoverem a justiça, o que se caracteriza pela ausência de preocupação e opressão aos órfãos e viúvas (v.17). Mesmo não aparecendo no texto os termos ger ou

\footnotetext{
${ }^{4}$ G. A Cooke não concorda com a inferência a Gênesis e diz que "os detalhes da culpa de Sodoma referem-se à Jerusalém e não a Gn 19". Cf. COOKE, 1936, p. 177. Contudo, outros autores reconhecem as relações com Gn 19, mas por sua diferença de ênfase, acreditam apontar para outra tradição ou apostam na ressignificação por conta do novo contexto social de Israel; cf. ZIMMERLI; CROSS; BALTZER, 1983, p. 350. Neste trabalho seguimos essa última hipótese.

${ }^{5}$ Alguns leitores usam esse texto para tratar da questão homoafetiva, o que nos parece violar o eixo do texto cujo centro está na falta de hospitalidade.
} 
nakri, eles podem ser pressupostos por intermédio da tradição dos grupos pobres ou fragilizados nos demais textos.

O conceito de justiça de Deus não pode ser desassociado das relações humanas e da equidade social. Aos grupos mais vulneráveis, os cuidados de Deus são disponibilizados e as tradições legais e proféticas desenvolvem o projeto da palavra viva de Javé cujo propósito é a luta por justiça, desenvolvimento do bem estar social, diminuição da exclusão e acolhimento humanizador. $\mathrm{O}$ amor, como experiência de partilha dos espaços e da nacionalidade, permite ao estrangeiro, como aos outros grupos em necessidade, a condição social indispensável para o bem viver. Como é afirmado no Código da Santidade, o estrangeiro se torna povo porque partilha da histórica condição do povo de Deus. Assim, como Deus os acolheu e os assentou, o povo peregrino de Israel precisa sentir as dores dos imigrantes e refugiados em suas terras. Isso não seria uma opção, mas ordem da vontade divina. Como bem explica o biblista judeu Nahum Sarna:

Quatro grupos sociais mais vulneráveis à exploração são agora apontados como objeto da preocupação especial de Deus: o forasteiro, a viúva, o órfão e o pobre. A Torá aqui mostra sensibilidade à sua condição, não simplesmente por considerações humanitárias, mas como um imperativo divino. A insensibilidade é consequentemente pecaminosa, uma violação de um mandamento que expressa a vontade de Deus. Uma característica marcante da formulação jurídica hebraica é a maneira pela qual o público é tratado no singular e no plural, seguindo o padrão do Decálogo. Ele reconhece tanto o indivíduo quanto a sociedade como igualmente responsáveis pelos termos do relacionamento da aliança entre Deus e Israel. O mal social é, portanto, um pecado contra a humanidade e contra Deus. (1991, p.137)

A justiça nas teologias da Bíblia Hebraica é o princípio ordenador do cosmo criado por Deus e encarna-se nas relações humanas, especialmente quando a equidade torna-se visível. Para isso, os grupos indicados como susceptíveis às mais ariscadas condições devem ser alvos das maiores preocupações. Para o YHWH descrito nas Escrituras judaicas, os estrangeiros, grupos humanos transeuntes por diversas razões, devem ser acolhidos como povo. Isso não é somente uma escolha, mas a única opção permitida por Deus. Dessa forma, há um possível modelo no Antigo Testamento para o trato com a mobilidade humana e seu acolhimento. O Deus dos códigos legais e da literatura profética torna a terra e seus bens lugar de todos e todas acessarem seus direitos, entre eles a recepção e a hospitalidade. Os refugiados são vítimas de diversos assaltos e injustiças, por isso devem preencher grande parte da agenda internacional. Não há fronteiras quando a dor é partilhada, porque o outro se torna, com sua alteridade, por conta da fragilidade, o lugar privilegiado de estabelecermos a vontade de Deus, que é Justo e Justificador dos que sofrem. 


\section{Teologia Bíblica a partir da tradição da migração e dos refugiados: Paroikoi e Parepidemoi}

A peregrinação no Novo Testamento mostra-se como o modo de ser da comunidade cristã (Lc 9,51-56; Jo 1,14; At 7,6; 10, 23-11,8; 1Pd 1,1). (ADRIANO FILHO, 2001, p. 24) Ef 2,19 ("não são estrangeiros e peregrinos, mas concidadãos dos santos, da família de Deus") torna casa de Deus aqueles e aquelas que se ajuntam à comunidade de Cristo, formando uma só família. Em Hebreus, por sua vez, aprofunda-se o caráter peregrino da comunidade dos seguidores e seguidoras de Jesus, tornando-a parte da tradição maior estabelecida desde Abraão:

\begin{tabular}{|c|c|}
\hline 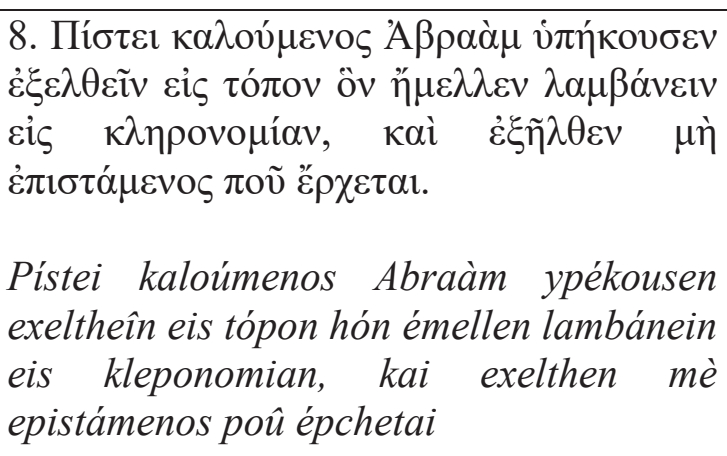 & $\begin{array}{l}\text { Pela fé, tendo sido chamado, Abraão } \\
\text { obedeceu partindo para o lugar reservado } \\
\text { para receber em herança, e foi não } \\
\text { sabendo para onde ia. }\end{array}$ \\
\hline 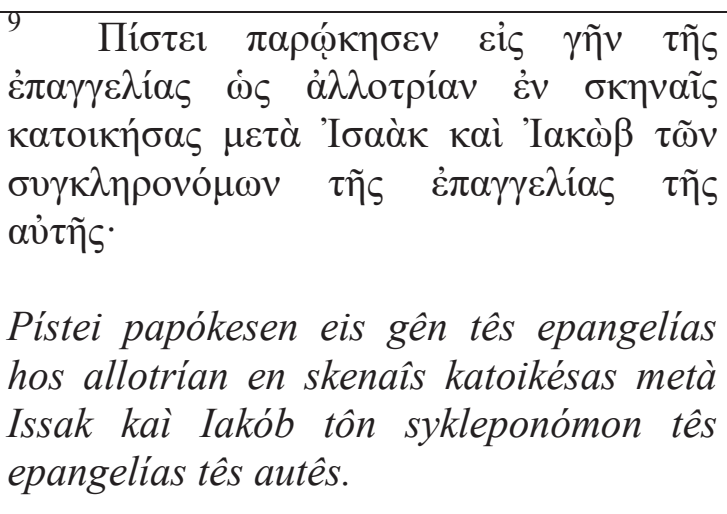 & $\begin{array}{l}\text { Pela fé refugiou-se na terra anunciada } \\
\text { como estrangeiro em tendas habitou como } \\
\text { Isaque e Jacó, coerdeiros da mesma } \\
\text { promessa. }\end{array}$ \\
\hline 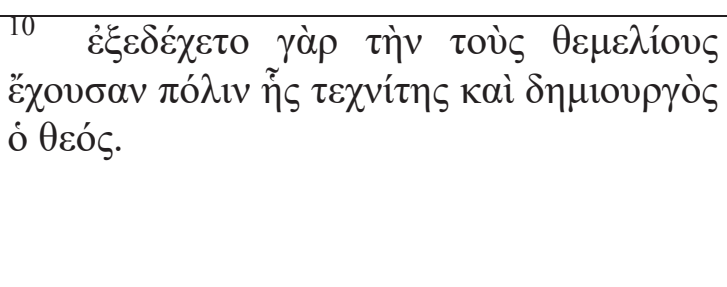 & $\begin{array}{l}\text { Aguarda, pois, a cidade que tem } \\
\text { fundamentos, para qual o arquiteto e } \\
\text { construtor é Deus. } \\
(\text { Hb11,8-10) }\end{array}$ \\
\hline
\end{tabular}

A imagem acima é desenvolvida em todo o texto de Hebreus, que tem como tema principal a peregrinação. Nesse livro neotestamentário, além dessa característica do povo de Deus, o próprio Jesus é modelo de movimentação, mas em caráter cósmico. Na segunda seção expositiva da carta, 4,14-10,25, encontramos o Filho como sumo sacerdote que migrou do céu, entrando 
em esfera terrena, e depois voltou aos céus onde se apresentou a si mesmo como sacrifício no santuário celestial (ADRIANO FILHO, 2001, p.102). Em $\mathrm{Hb}$ 4,14-15 ele é tratado como o sumo sacerdote que "atravessou o céu". O

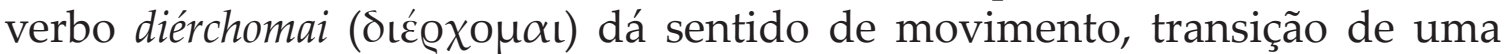
região para outra, que aqui se refere a Jesus que atravessou o céu tornando-se solidário à condição humana. O Deus encarnado é peregrino celestial que se arrisca à condição humana e partilha por um tempo sua peregrinação.

Em Hebreus, Abraão é paradigma do peregrino (paroikos). No entanto, essa peregrinação, em Hebreus, precede à realidade celestial e torna o fiel alguém em passagem. Mesmo que essa imagem seja muito relevante, inclusive por colocar Jesus cósmico como o grande modelo, a ênfase na vida celestial torna a realidade histórica menor, passageira e não importante. Com esse peso transcendente, gerou-se, em muitos, a despreocupação com os problemas humanos, o pouco engajamento contra as contradições sociais ou a passividade diante das questões da vida, por interpretarem esse mundo com simples passagem, uma tragédia momentânea prestes a ser substituída. Consequentemente, até a leitura bíblica torna-se desencarnada. Por isso, 1 Pedro, e suas leituras sociológicas podem ser de grande valia para a discussão e diálogo com Hebreus.

Um passo significativo na exegese de 1 Pedro foi a abordagem sociológica feita por J. Elliott ${ }^{6}$, o que fez avançar as pesquisas para o lugar social do texto. Seguindo esses trabalhos, podemos afirmar que a carta petrina foi escrita para exortar e fortalecer cristãos identificados logo no prólogo do livro como parepidemoi (forasteiros migrantes) $(1,1)$ e paroikoi (estrangeiros residentes) $(1,17 ; 2,11)$. Esses dois termos representam categorias sociais. Os paroikoi eram os estrangeiros que tinham adquirido o direito de residência, mas não desfrutavam dos direitos adquiridos pelos cidadãos. Os parepidemoi, por sua vez, eram os estrangeiros que não possuíam nem mesmo o direito de residência. Esses grupos eram estranhos de cultura, língua, costumes, filiação política, social ou religiosa do contexto da Ásia Menor (ELLIOTT, 2000). Não gozavam de nenhum direito político, não podiam participar das assembleias populares e eram excluídos do serviço militar. Elliott descreveu a situação dos paroikoi (que no latim equivale a peregrinus) romanos da seguinte maneira:

Os peregrinos não gozavam de nenhum direito político, não podiam participar das assembleias populares e eram excluídos do serviço militar. Um peregrinus só poderia contrair matrimônio válido (iustae nuptiae) quando gozava do iusconnubii (...). Não poderia constituir-se herdeiro de um cidadão romano nem receber delegação, exceto no testamento de um soldado. Poderia realizar transação comercial com um cidadão romano se possuísse o iuscommercii que se concedia da mesma forma que o iusconnubii. (ELLIOTT, 1985, p. 41)

${ }^{6}$ Cf. ELLIOTT, 2000; ELLIOTT, 1985. 
Eram judeus e pagãos que encontraram na comunidade cristã aceitação e casa, ou seja, a oikos thou theou (casa de Deus). Engrossando as fileiras das comunidades cristãs dos primeiros dois séculos, os paroikoi e parepidemoi deveriam, também, ser estranhos à vida imoral daqueles que os cercavam. Essa postura criou um caráter exclusivista na comunidade, gerando perseguições por causa do estranhamento dos seus concidadãos. Segundo a epístola, no entanto, não deveriam desistir de se portarem como separados (1,6.14.22; 4, 12-16). O caráter distintivo dos cristãos petrinos em relação aos não cristãos se limitava à ordem temporal e histórica $(2,11-12 ; 1,17)$.

É importante ressaltar que a perseguição a esses estrangeiros se resumia a injúrias, difamações e acusações infundadas $(2,12.15 ; 3,14 s s ; 4.3)$. Essa interpretação presume não haver uma perseguição civil, corroborando, assim, com a passividade em relação ao Estado $(2,13)^{7}$. O governo romano aqui não é considerado nem "como servo de Deus" (Rm 13, 1-7) nem como "suporte de Satã" (Apocalipse), mas como instituição humana que administra a justiça (1 Pd 2, 13-14) e digna de respeito $(2,17)$.

1 Pedro torna-se, nessa perspectiva, um consolo e encorajamento histórico aos paroikoi e parepidemoi na época do Imperador Vespasiano (69-79). (TERRA, 2008, p. 221) O grande consolo estava em saber que, mesmo sendo estranhos e forasteiros, ainda eram da família ou casa de Deus $(2,5 ; 4,17)$. A casa significava abrigo para quem não tinha residência e identidade. Para os paroikoi, a identificação como casa eleita e santa de Deus servirá como eficaz instrumento social de identificação comunitária (peculiar e distintiva) e integridade sociorreligiosa.

No contexto do acolhimento dos peregrinos e migrantes, a philadelphia ( $\phi(\lambda \alpha \delta \varepsilon \lambda \phi \dot{\alpha} \alpha)$ e o amor fraternal partilhado ( $\dot{\alpha} \lambda \lambda \eta \dot{\lambda} \lambda$ ov $\dot{\alpha} \gamma \alpha \pi \eta \dot{\sigma} \sigma \alpha \tau \varepsilon)$ estabeleceriam a estrutura da comunidade (1Pd 1,22). No catálogo de vida comunitária, no mesmo discurso de autodomínio, sobriedade e oração, a carta reafirma a necessidade do amor mútuo cuja presença cobre uma multidão de pecados (1Pd 4,7-8). Segundo a epístola, esse amor alcança a prática da hospitalidade, porque está a serviço uns dos outros, como bons despenseiros da multiforme graça de Deus (1Pd 4, 7-10). O conceito usado no texto para "hospitalidade" é philoxenoi ( $\phi \iota \lambda o ́ \xi \varepsilon v o \iota):$ amor pelo estrangeiro. $\mathrm{O}$ acolhimento ao estrangeiro, nesse sentido, seria uma prova do amor e da presença da graciosidade divina. (ACHTEMEIER, 1996, p. 297)

A prática da hospitalidade é indicada em $\mathrm{Rm} 12,13$ e $\mathrm{Hb}$ 13,2. No Novo Testamento ser hospitaleiro é uma qualidade desejável nos líderes da igreja (1Tm 3,2; Tt 1,8). Existem numerosas ilustrações dessa prática na

\footnotetext{
${ }^{7}$ É importante compararmos com a passagem de 5,9, na qual se pressupõe uma perseguição universal.
} 
literatura neotestamentária (isto é, At 16,15; Rm 16, 5.23). H. Marshall, ao ler esta parte, pergunta se a necessidade dessa prática é menor hoje do que no Mundo Antigo (MARSHALL, 1991). Sua dúvida é possível porque sua leitura é muito reduzida à realidade da prática interna das comunidades cristãs. $\mathrm{O}$ acolhimento em amor, o amor ao estrangeiro e a construção da comunidade do serviço partilhado serve de modelo para uma teologia bíblica da hospitalidade e do trato com as pessoas em migração de forma abrangente.

Como espaço de acolhimento, as relações humanas precisam preservar seu caráter de hospitalidade. Isso tornará as pessoas lançadas em terras estranhas em irmão/as e companheiros/as coparticipantes da casa de Deus. Assim, a imigração causada por desemprego e/ou crise humanitária torna-se um lugar privilegiado para leitura de 1Pedro e do Novo Testamento, o que modelará a missão da Igreja.

A ideia de casa de Deus estende-se para a grande oikoumene, onde se estabelecem as relações internacionais, abrindo a discussão sobre a promoção da vida e defesa dos direitos dos que buscam refugio por conta da guerra, fome ou peste. A próprio fé no Cristo migrante e refugiado entre os homens - segundo a tradição de Mateus essa seria sua condição desde o nascimento (Mt 2,13-23) - mostra-se como modelo para as comunidades de fé, porque quando se acolhe um estrangeiro (xenos) acolhe-se o próprio Cristo (Mt 25, 35-41).

\section{Conclusão}

A Declaração de Cartagena, que aprofundou o conceito de refugiado e abriu novos horizontes para a proteção internacional, surgiu no contexto dos conflitos que afetaram gravemente a América Central no final dos anos setenta e principalmente durante os anos oitenta (CARNEIRO, 2012, p. 13). Segundo essa declaração,

... face à experiência adquirida pela afluência em massa de refugiados na América Central, se torna necessário encarar a extensão do conceito de refugiado tendo em conta, no que é pertinente, e de acordo com as características da situação existente na região, o previsto na Convenção da OUA (artigo 1., parágrafo 2) e a doutrina utilizada nos relatórios da Comissão Interamericana dos Direitos Humanos. Deste modo, a definição ou o conceito de refugiado recomendável para sua utilização na região é o que, além de conter os elementos da Convenção de 1951 e do Protocolo de 1967, considere também como refugiados as pessoas que tenham fugido dos seus países porque a sua vida, segurança ou liberdade tenham sido ameaçadas pela violência generalizada, a agressão estrangeira, os conflitos internos, a violação maciça dos direitos humanos ou outras circunstâncias que tenham perturbado gravemente a ordem pública. (DECLARAÇÃO DE CARTAGENA, III) 
Adotada pelo Colóquio sobre Proteção Internacional dos Refugiados na América Central, México e Panamá, realizado em Cartagena, Colômbia, em novembro de 1984, esse documento é um avanço nas discussões a respeito da migração, refugiados e direitos humanos. Com as guerras, catástrofes ou fome, a realidade de pessoas em trânsito ao redor do planeta tornou-se dramática, o que significa sempre a violação de direitos básicos.

No Brasil, a discussão a respeito da migração tem ganhado caráter de lei. A nova Lei de Migração brasileira (Lei no 13.445, de 24 de maio de 2017), apesar dos vetos, representa um grande avanço no trato da questão migratória no país e abre a perspectiva de esperança para os coletivos migrantes que já se encontram por aqui, para aqueles que estão por vir e para os brasileiros que emigraram para o exterior. (OLIVEIRA, 2017)

Diante dessa realidade urgente, a teologia precisa pensar sua fé, desenvolver seus discursos missionais e travar disputas de narrativas a partir de uma teologia bíblica preocupada com a complexa discussão a respeito desse tema. Para isso, o conceito de justiça na tradição bíblica mostrará Javé como o Deus ordenador cuja preocupação está especialmente voltada para o auxílio e socorro dos que sofrem, entre os quais estão os estrangeiros que devem ser acolhidos pelo povo de YHWH. Deus como modelo de amor e segurança serve de paradigma nas relações humanas, que precisam se estabelecer eticamente, significando não oprimir o necessitado e, mais do que isso, ajudá-lo em suas fragilidades, porque o povo de Israel conhece bem a condição de estrangeiro.

No Novo Testamento, a própria imagem de Jesus como migrante celestial em terras humanas dá à encarnação caráter de compaixão com a realidade dos peregrinos humanos. Por sua vez, os paroikoi e parepidemoi acolhidos nas comunidades cristãs da Ásia Menor são modelos de atuação internacional, cuja ação precisa pensar políticas internacionais para a migração a partir da philadelphia e philoxenos. Assim, a comunidade de peregrinos precisa se posicionar e militar pelo estabelecimento dos direitos dos refugiados, pois testemunhará sua colaboração e participação no projeto de construção da casa de Deus, a casa comum, a oikoumene de todos e todas.

\section{Referências}

ACHTEMEIER, P. J. 1 Peter: A commentary on First Peter. Minneapolis: Fortress Press, 1996. (Hermeneia: A Critical and Historical Commentary on the Bible).

ADRIANO FILHO, J. Peregrinos neste mundo: simbologia religiosa na Epístola aos Hebreus. São Paulo: Loyola, 2001.

BRASIL. Constituição da República Federativa do Brasil. 1988. 
CARNEIRO, W. P. A Declaração de Cartagena de 1984 e os desafios da proteção internacional dos refugiados, 20 anos depois. In: SILVA, C. A. da (Org.). Direitos humanos e refugiados. Dourados: UFGD, 2012. p. X-XX.

COMPARATO, K. F. Fundamentos dos Direitos Humanos. Instituto de Estudos Avançados da Universidade de São Paulo, São Paulo. Disponível em <http://www.iea.usp.br/ publicacoes/textos/comparatodireitoshumanos.pdf/view>. Acesso em: 16 mar. 2019. Afirmação histórica dos Direitos Humanos. 11.ed. São Paulo: Saraiva, 2017.

COOKE, G. A. A Critical and Exegetical Commentary on the Book of Ezekiel. Edinburgh: T. \& T. Clark, 1936.

CRÜSEMANN, F. A Torá: Teologia e história social da lei do Antigo Testamento. 2.ed. Petrópolis: Vozes, 2001.

ELLIOTT, J. H. Um lar para quem não tem casa: introdução sociológica a primeira carta de Pedro. São Paulo: Paulinas, 1985.

. 1 Peter: a New Translation with Introduction and Commentary. New York: Doubleday2000. (The Anchor Bible 37 B).

DECLARAÇÃO DE CARTAGENA. Disponível em: <https://www.pucsp.br/IIIseminariocatedrasvm/documentos/declaracao_de_cartagena.pdf $>$. Acesso em: 10 jul. 2019.

G1.COM. Jovem saudita que fugiu da família ganha status de refugiada. Disponível em: https://g1.globo.com/mundo/noticia/2019/01/09/jovem-saudita-que-fugiu-da-familia-ganha-status-de-refugiada.ghtml Acesso em: 10 jan. 2019.

HABERMAS, J. Racionalidade e comunicação. Lisboa: Edições 70, 2002.

HOLLADAY, W. L., KÖHLER, L. A concise Hebrew and Aramaic Lexicon of the Old Testament. Leiden. Boston. Köln: Brill, 2000.

JENNI, E.; WESTERMANN, C. Theological Lexicon of the Old Testament. Massachusetts: Hendrickson, 2004. v. 3.

MARSHALL, I. H. 1 Peter. The IVP New Testament commentary series. Downers Grove, Ill.: InterVarsity Press, 1991.

MAZZUOLI, V. de O. Curso de Direitos Humanos. São Paulo: Editora Método, 2017.

OLIVEIRA, A. T. R. Nova lei brasileira de migração: avanços, desafios e ameaças. Revista Brasileira de Estudo Populacionais, São Paulo, n. 1, v.34, jan./abr. 2017.

PADILLA, C. R. Rumo a uma hermenêutica contextual. Estudos Teológicos, São Leopoldo, n. 3, v. 24, p. 225-249, jan./abr. 1984.

PELAEZ, A. C. et al. História da Teologia na América Latina. 2.ed. São Paulo: Paulinas, 1985.

PIOVESAN, F. Temas de Direitos Humanos. São Paulo: Saraiva, 2018.

Comentários ao artigo IV da Constituição da República Federativa do Brasil. In.: CANOTILHO, J. J. G. et al. Comentários à Constituição do Brasil. São Paulo: Saraiva; Almedina, 2013. p. $154-174$.

RAMOS, A. de C. Curso de Direito Constitucional. São Paulo: Saraiva, 2018.

RIVERO, J.; MOUTOUH, H. Liberdades públicas. São Paulo: Martins Fontes, 2006. 
SARNA, N. M. Exodus: the JPS Torah commentary. Philadelphia: Jewish Publication Society, 1991.

STAM, J. A Bíblia, o leitor e seu contexto histórico. Pautas para uma hermenêutica evangélica contextual. Boletim Teológico: Revista do Setor Brasil de Fraternidade Teológica Latino-Americana, São Leopoldo, n. 3, p. 92-136, mai./ago. 1984.

TABORDA, F. Métodos Teológicos na América Latina. Perspectiva Teológica, Belo Horizonte, v. 19, n. 49, p. 293-319, set./dez. 1987.

TERRA, K. R. C. A comunidade apocalíptica de 1 Pedro: o sofrimento como anúncio consolador escatológico. In: REIMER, H.; SILVA, Valmor da. (Orgs.). Libertação - Liberdade. Novos olhares: contribuições ao II Congresso Brasileiro de Pesquisa Bíblica. São Leopoldo: Oikos; Goiânia: UCG, 2008.

VAZ, A. dos Santos. O específico da justiça na Bíblia Hebraica. Cultura: Revista de História e Teorias das Ideias, v. 30, p. 63-75, 2012. Disponível em: <https://journals. openedition.org/cultura/1563>. Acesso em: 08 ago. 2019.

WOLKMER, A. C. Cultura jurídica moderna, humanismo renascentista e Reforma Protestante". Sequência, Florianópolis, n. 50, p. 9-27, jul. 2005.

ZIMMERLI, W.; CROSS, F. M.; BALTZER, K. Ezekiel : A Commentary on the Book of the Prophet Ezekiel. Philadelphia: Fortress Press, 1983. v. 2.

Artigo submetido em 19.03.2019 e aprovado em 08.08.2019.

Adriano Sousa Lima é doutor em Teologia pela Pontifícia Universidade Católica do Paraná (PUCPR -2016), professor de Teologia no Centro Universitário Internacional (UNINTER) e professor no Programa de Mestrado Profissional em Teologia na Faculdade Batista do Paraná. Contribuição no artigo: estruturação em parceria do esboço, produção da exposição histórico-teórica das políticas internacionais para os Direitos Humanos dos Refugiados, leitura crítica da introdução e conclusão, correção do texto final. Orcid.org/0000-0002-8337-1573. E-mail: adriano.lima.66@hotmail.com

Endereço: R. 13 de Maio, 439 /1102B - Centro

80.020-270 Curitiba - PR

Kenner Roger Cazotto Terra é doutor em Ciências das Religiões pela Universidade Metodista de São Paulo (UMESP - 2015) e professor de Teologia no Programa de Mestrado Profissional em Ciências das Religiões na Faculdade Unida de Vitória.

Contribuição no artigo: estruturação em parceria do esboço, produção da discussão bíblico-teológica a respeito do tema dos direitos humanos dos refugiados, desenvolvimento da introdução, a escrita da conclusão e a correção do texto final. Orcid.org/0000-0002-2007-6745. E-mail: kenner@faculdadeunida.com.br

Endereço: R. Eng. Fábio Ruschi, 161 - Bento Ferreira, 29050-670 Vitória - ES 